\title{
Durum wheat salt stress tolerance is modulated by the interaction between plant genotypes, soil microbial biomass, and enzyme activity
}

\author{
Khaoula Boudabbous, ${ }^{1,2}$ Imen Bouhaouel, ${ }^{1}$ Nadhira Benaissa, ${ }^{1}$ Maroua Jerbi, ${ }^{2}$ Youssef Trifa, ${ }^{1}$ \\ Ali Sahli, ${ }^{1}$ Chahine Karmous, ${ }^{1}$ Hajer S. Amara ${ }^{1}$ \\ ${ }^{1}$ Genetics and Cereal Breeding Laboratory (LR14AGR01); and ${ }^{2}$ Horticultural Sciences Laboratory \\ (LR13AGR01), National Agronomic Institute of Tunisia, University of Carthage, Tunis-Mahragene, Tunisia
}

\author{
Highlights \\ - Salt-tolerant durum wheat genotypes showed greater microbial activities in the rhizosphere. \\ - Microbial enzymatic changes depended on the interaction plant genotype $\times$ soil salinity. \\ - $\quad$ The $M B C / M B N$ ratio and dehydrogenase strongly correlated with grain yield under salinity. \\ - $\quad M B C$, available $N$, and alkaline phosphatase as predictors of grain yield at $12 \mathrm{dS} \mathrm{m} \mathrm{m}^{-1}$. \\ - Tillering and flowering could be key stages of durum wheat salinity tolerance.
}

\begin{abstract}
Understanding the relationship between durum wheat genotypes and soil biochemistry under salt stress plays a key role in breeding for yield superior genotypes. Thus, microbial biomass carbon (MBC) and nitrogen (MBN), the activity of three selected enzymes including dehydrogenase (D-ase), alkaline phosphatase (Alk-ase), and protease (P-ase), and available phosphorus (available $\mathrm{P}$ ) and nitrogen (available N) were assessed. Two landraces and two improved varieties were tested under two salinity levels of water irrigation ( 0.3 and $\left.12 \mathrm{dS} \mathrm{m}^{-1}\right)$. Soil sampling was carried out at five
\end{abstract}

Correspondence: Khaoula Boudabbous, Genetics and Cereal Breeding Laboratory (LR14AGR01) and Horticultural Sciences Laboratory (LR13AGR01), National Agronomic Institute of Tunisia, University of Carthage, Tunis-Mahragene 1082, Tunisia.

E-mail: khaoulaboudabbous15@gmail.com

Key words: Durum wheat; enzymatic activities; growth stages; microbial biomass; salinity; yield.

Acknowledgements: this work was financially supported by the Tunisian Ministry of Agriculture. We are grateful to Dr Rahma Ines Zoghlami from Water Research and Technology Center for helping us with enzymatic analysis.

See the online Appendix for additional material.

Received for publication: 7 July 2021.

Revision received: 1 January 2022.

Accepted for publication: 5 January 2022.

CCopyright: the Author(s), 2022

Licensee PAGEPress, Italy

Italian Journal of Agronomy 2022; 17:1942

doi:10.4081/ija.2022.1942

This article is distributed under the terms of the Creative Commons Attribution Noncommercial License (by-nc 4.0) which permits any noncommercial use, distribution, and reproduction in any medium, provided the original author(s) and source are credited. durum wheat growth stages. The soil biota-genotype interaction seems to affect the biological (MBC, MBN, and enzymatic activities) and chemical (available $\mathrm{P}$ and $\mathrm{N}$ ) traits. The microbial activity of rhizospheric soil was higher at the tillering and flowering stages. Under saline conditions, 'Maali' (improved variety) and 'Agili Glabre'(landrace) showed the best belowground inputs (e.g., MBC, MBN, enzymatic activities, available $\mathrm{P}$ and $\mathrm{N}$ ) and grain yield (GY) performance. Under the same conditions, four soil biochemical indicators of GY of tolerant genotypes (i.e., 'Maali' and 'Agili Glabre') were determined as available N, P-ase, available P, Alkase, and D-ase. Stepwise analysis revealed that predictive variables depended on growth stages. Overall, MBC, available N, Alk-ase, and P-ase were the variables that mainly contributed to predicting GY in saline environments. In conclusion, the results suggested a specific interaction between plant genotype roots and soil microbes to overcome salt stress. Thus, soil biological components should acquire more importance in plant salinity tolerance studies.

\section{Introduction}

Due to irregular rainfall events, supplementary irrigation constitutes the primary agronomical practice in arid and semi-arid regions to increase crop productivity (Frija et al., 2014). Competition for water resources among different social and economic sectors increased drastically at the expense of the agricultural sector. Crop needs are threatened by limited available water resources leading to the use of poor water quality irrigation, mainly characterised by various levels of salinity (Shahbaz and Ashraf, 2013) ranging from 1.5 to $15 \mathrm{dS} \mathrm{m}^{-1}$ (Biro Turk and Aljughaiman, 2020). Durum wheat (Triticum turgidum L. ssp. durum [Desf.] Husn.), as a glycophyte, is recognised for its low tolerance to salinity (Munns et al., 2006). Hence, we need to develop genotypes with better tolerance to salinity stress and thus have a greater yield (Chaabane et al., 2011). In Tunisia, since the twentieth century, several breeding programs have been conducted to select the best performing genotypes against abiotic stresses to achieve optimum yield (Sayar et al., 2010; Slim et al., 2019). Throughout genotypic screening, salt stress tolerance ongoing breeding programs showed that wheat landraces could be considered useful gene reservoirs (Chaabane et al., 2011). In general, durum wheat breeding programs worldwide have focused mainly on the aboveground crop traits, neglecting the 
belowground parts of the plant (Rassaa et al., 2012).

Salinity is also considered a limiting factor of soil biological processes involved in the cycle of nutrients (Fageria et al., 2011). It is well established that soil salinity stress reduces microbial biomass, and enzyme activity, with significant reductions in nitrogen $(\mathrm{N})$ mineralisation and phosphorus (P) availability (Boyrahmadi and Raiesi, 2018). Reduction in enzyme activities under salt stress may be attributed to lower microbial growth and biomass; thereby, fewer enzymes are released in soil (Lu et al., 2015). Hence, studying how microbial indicators respond to salinity and interact with plants could be important to develop a proper strategy for agriculture to restore the use of saline water in arid areas efficiently.

Up-to-date, the response of microorganisms to plant species has been extensively studied (Corneo et al., 2016; Zhu et al., 2017), while interaction between plant genotypes and rhizospheric microorganisms under saline conditions has received less attention. Different wheat genotypes could differentially provoke changes in soil quality, including microbial biomass carbon (MBC) and nitrogen $(\mathrm{MBN})$, and the enzymatic activity that positively or negatively affects their performance (Zuo et al., 2014; Corneo et al., 2016). Otherwise, MBC, MBN, and dehydrogenase activity differed considerably according to wheat physiological stages under non-saline conditions (Mandal et al., 2007). Nonetheless, a paucity of studies is available on microbial activities under different growth stages (Bera et al., 2018; Jat et al., 2020). It is important to consider soil biotagenotype interaction during the developmental cycle when assessing plant salinity tolerance. Here, the main objective was to investigate the interaction of four durum wheat genotypes (landraces and improved varieties) with the biological and chemical properties of the rhizosphere at five growth stages and two salinity levels. In the light of the above purpose, the specifics objectives were to: i) evaluate the effect of salinity on microbial indicators and chemical properties; ii) assess the pattern of fluctuation of rhizosphere variables during crop growth; and iii) determine the correlations between microbial and chemical characteristics, and wheat productivity assessed as grain yield.

\section{Materials and methods}

\section{Plant material}

Four durum wheat (Triticum turgidum L. ssp. durum [Desf.] Husn.) genotypes comprising two landraces ('Agili Glabre' and 'Bayadha') and two improved varieties ('Maali' and 'Razzek') were chosen based on their salt stress tolerance. Thus, 'Agili Glabre' and 'Maali' are considered as salt-tolerant genotypes to $12 \mathrm{dS} \mathrm{m}^{-1}$, while 'Bayadha' and 'Razzek' are recognised as salt-sensitive genotypes to this level of salinity (Boudabbous et al., 2016; Boudabbous et al., 2019).

\section{Experimental design and plant growth conditions}

Two hundred pots $(25 \mathrm{~cm}$ diameter $\times 25 \mathrm{~cm}$ height, $7 \mathrm{~kg}$ of soil $)$ were placed in a semi-closed environment at the National Agronomic Institute of Tunisia ( $\left.36^{\circ} 49^{\prime} \mathrm{N}, 10^{\circ} 10^{\prime} \mathrm{E}\right)$ during the growing season 2018-2019. A shelter was used to prevent the leaching of salt by rainwater. The minimum and the maximum air temperature and relative humidity recorded during the experiment ranged between $10-35^{\circ} \mathrm{C}$ and $57-70 \%$, respectively. The soil was collected from the surface layer $(0-20 \mathrm{~cm})$ of a field $\left(35^{\circ} 34^{\prime} 33^{\prime}\right.$ N , $10^{\circ} 2^{\prime} 48^{\prime}$ E) and had a clay-loamy texture (USDA, 2013) (Table 1). The collected soil was sieved ( $2 \mathrm{~mm}$ mesh size). Ten seeds were sown on December 23, 2018, thinned to five plants after emergence for each pot. Randomised complete block design with five replicates per treatment $(n=5)$ was used to accommodate the two-way factorial experiment, with genotypes (04) and level of salinity $\left(0.3 \mathrm{dS} \mathrm{m}{ }^{-1}\right.$ [control] and $12 \mathrm{dS} \mathrm{m}^{-1}$ [saline or brackish water]) as main factors. Irrigation was applied with tap water to reach soil moisture with $100 \%$ water-holding capacity to exclude the water-deficit stress. Salt stress was applied two weeks after sowing. To maintain saturation levels throughout the experiment, the amount of water losses was completed and estimated by the weight difference of each pot between two successive days. Nitrogen fertilisation was carried out using $0.7 \mathrm{~g}$ of ammonium nitrate $(33.5 \% \mathrm{~N})$ per pot and applied at 3 leaves (Z13), 6 leaves (Z16), and two nodes (Z32) durum wheat growth stages (Zadoks et al., 1974). To avoid heat stress effects and standardise the experiment conditions, the position of the blocks (40 pots per block) was interchanged every two days, maintaining the position of pots within each block which encompasses five replicates per treatment. The plants were maintained under these conditions for six months. The number of grains per plant (NG), and grain yield per plant $(\mathrm{GY}, \mathrm{g})$ were recorded at maturity.

\section{Soil sampling}

The soil samples were collected ( 0 to $20 \mathrm{~cm}$ depth) at five crop growth stages (six leaves, 30 days old crop [Z16]; tillering, 70 days old crop [Z30]; flowering, 100 days old crop [Z65]; maturity, 135 days old crop [Z85]; and after harvest [Z92]) (Zadoks et al., 1974). During sampling and with each growth stage, one replicate per treatment was chosen from each block. For each growth stage, the pots were overturned for sampling. Three rhizosphere soil cores $(2.5$ of diameter $\times 20 \mathrm{~cm}$ deep) strongly adhering to the roots were extracted $(\sim 300 \mathrm{~g})$ from each pot using a spade. The collected soil was homogenised and sieved using a $2 \mathrm{~mm}$ mesh to remove any remaining wheat roots. Subsequently, soil samplings were divided into two parts and placed into sterilised plastic bags. The first part was dried out to analyse the physico-chemical properties of the soil, and the second part was stored at $4^{\circ} \mathrm{C}$ for biological assessment.

\section{Physico-chemical analysis}

Before sowing, the electrical conductivity (EC), $\mathrm{pH}_{\text {water, }}$, soil organic carbon $\left(\mathrm{C}_{\text {org }}\right)$, total calcium carbonate $\left(\mathrm{CaCO}_{3}\right)$, total $\mathrm{N}$, and soil texture were analysed (Table 1). The $\mathrm{EC}$ and $\mathrm{pH}_{\text {water }}$ were determined according to $1: 5(\mathrm{w} / \mathrm{v})$ soil water suspension at $25^{\circ} \mathrm{C}$ (AFNOR, 1995). $\mathrm{C}_{\text {org }}$ was determined by dichromate oxidation (Walkley and Black, 1934), while the Bernard Calcimeter classical method was used to measure total $\mathrm{CaCO}_{3}$ (Petard, 1993). Finally, total $\mathrm{N}$ and available $\mathrm{N}$ were determined using the method outlined by Kjeldahl (Waring and Bremner, 1964). Soil available P and N were estimated before sowing (Table 1) and during durum wheat growth stages (Z16, Z30, Z65, Z85, and Z92). Available P was quantified by blue-colorimetry (Olsen et al., 1954).

\section{Soil microbial biomass carbon and nitrogen}

Microbial biomass carbon (MBC) and microbial biomass $\mathrm{N}$ (MBN) were determined before (Table 1) and after sowing (Z16, Z30, Z65, Z85, and Z92) by the chloroform-fumigation extraction method (Vance et al., 1987). MBC and MBN were calculated using a conversion factor $\left(\mathrm{K}_{\mathrm{C}}=0.49\right.$ and $\left.\mathrm{K}_{\mathrm{N}}=0.20\right)$ as described by Brookes et al. (1985).

\section{Enzymes essays}

Activities of three enzymes involved in $\mathrm{C}, \mathrm{P}$, and $\mathrm{N}$ cycling were analysed before (Table 1) and after sowing (Z16, Z30, Z65, Z85, and Z92) as dehydrogenase (D-ase) as C-acquiring enzyme, phosphatase alkaline (Alk-ase) as $\mathrm{P}$-acquiring enzyme, and protease (P-ase) as $\mathrm{N}$ acquiring enzymes. Enzyme activities were estimated using the col- 
orimetric methods described below. The D-ase activity was evaluated by monitoring the reduction of iodonitrotetrazolium (INT) to iodonitrotetrazolium formazan (INTF) (Kumar et al., 2013).

The activity of Alk-ase was estimated based on $p$-nitrophenol ( $p$-NP) release after cleavage of $p$-nitrophenyl phosphate ( $p$-NPP) (Tabatabai and Bremner, 1969). Finally, the protocol described by Ladd and Butler (1972) was used to quantify the P-ase activity.

\section{Statistical analysis}

Agronomic and soil variables were compared using analysis of variance (ANOVA) and Tukey's HSD post-hoc test at 5\% significance level in the $\mathrm{R}$ environment version 3.6.0. The $\mathrm{R}$ package ggplot2 was used for more advanced graphics (Wickham, 2009). The Pearson coefficients $(r)$ were used to assess correlations between the chemical (i.e., available $\mathrm{P}$ and $\mathrm{N}$ ) and biological parameters (i.e., MBC, MBN, D-ase, Alk-ase, and P-ase) for each salinity level and growth stage using the 'Cor' function and were subsequently visualised in the 'Corrplot' package of the $\mathrm{R}$ environment version 3.4.3 (Wei et al., 2017). In addition, simple and multiple linear regression analyses (stepwise) were run to describe the relationships of GY data with the biochemical traits of the soil.

\section{Results}

\section{Variation of microbial biomass carbon and nitrogen}

The ANOVA showed for each growth stage that soil MBC and MBN levels were significantly $(\mathrm{P} \leq 0.001)$ dependent on the applied salinity $(\mathrm{S})$, the durum wheat genotypes $(\mathrm{G})$, and the interaction between the salinity and genotypes $(\mathrm{S} \times \mathrm{G})$ (Table $\mathrm{S} 1)$. During the development cycle, MBC and MBN increased gradually from the six leaves stage (Z16) and reached the maximum at vegetative
(Z30) and flowering stages (Z65). Thereafter, MBC and MBN declined at maturity (Z85) and showed the lowest amount at the full maturity of grain (Z92) (Table S1, Figure 1). The salinity reduced the rhizosphere $\mathrm{MBC}$ and $\mathrm{MBN}$ contents by $14-38 \%$ and $16-36 \%$, respectively, with a slight increase at tillering for $\mathrm{MBN}$. The effect

Table 1. Initial physical, chemical, and biological properties of soil used in the pot experiment.

\begin{tabular}{|c|c|c|}
\hline Parameters & Value & Unit \\
\hline $\mathrm{EC}$ & $1.22^{*}$ & $\mathrm{dS} \mathrm{m}^{-1}$ \\
\hline $\mathrm{pH}_{\text {water }}$ & 7.92 & - \\
\hline $\mathrm{C}_{\text {org }}$ & 11.00 & $\mathrm{mg} \mathrm{kg}^{-1}$ \\
\hline $\mathrm{CaCO}_{3}$ & 31.80 & $\mathrm{mg} \mathrm{kg}^{-1}$ \\
\hline Total N & 1.20 & $\mathrm{mg} \mathrm{kg}^{-1}$ \\
\hline $\mathrm{C} / \mathrm{N}$ & 9.16 & - \\
\hline Sand & 14.82 & $\%$ \\
\hline Loam & 33.77 & $\%$ \\
\hline Clay & 49.10 & $\%$ \\
\hline Texture & Clay-loamy & - \\
\hline Available P & 5.50 & $\mathrm{mg} \mathrm{kg}^{-1}$ \\
\hline Available N & 15.5 & $\mathrm{mg} \mathrm{kg}^{-1}$ \\
\hline $\mathrm{MBC}$ & 134.00 & $\mathrm{mg} \mathrm{C} \mathrm{kg}{ }^{-1}$ \\
\hline MBN & 15.56 & $\mathrm{mg} \mathrm{N} \mathrm{kg}^{-1}$ \\
\hline D-ase & 7.34 & $\mu g$ INTF g ${ }^{-1} h^{-1}$ \\
\hline Alk-ase & 5.47 & $\mu g p-\mathrm{NP} \mathrm{g}^{-1} \mathrm{~h}^{-1}$ \\
\hline P-ase & 20.42 & $\mu g$ tyr $g^{-1} h^{-1}$ \\
\hline
\end{tabular}

EC, electrical conductivity; $\mathrm{C}_{\text {org, }}$, organic carbon; $\mathrm{CaCO}_{3}$, total calcium carbonate; Available $\mathrm{P}$, available phosphorus; Available N, available nitrogen; $\mathrm{C} / \mathrm{N}$, carbon nitrogen ration; $\mathrm{MBC}$, microbial biomass carbon; MBN, microbial biomass nitrogen; D-ase, dehydrogenase; Alk-as, alkaline phosphatase; P-ase, protease. *Data are presented as the mean of three replicates ( $\mathrm{n}=3)$.

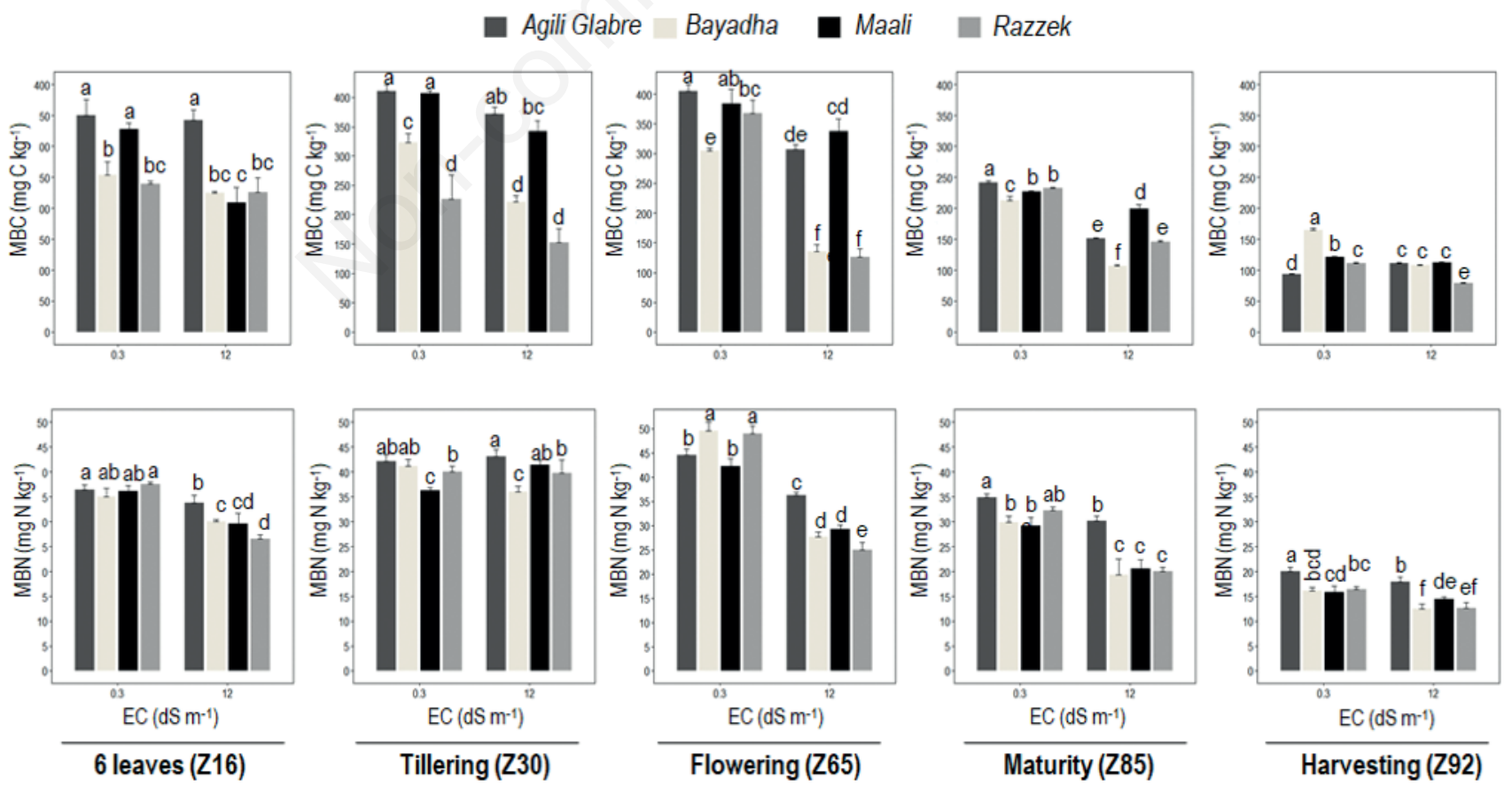

Figure 1. Variation of microbial biomass-C (MBC) and $\mathrm{N}(\mathrm{MBN})$ at five growth stages of durum wheat crop under non-saline $(0.3 \mathrm{dS}$

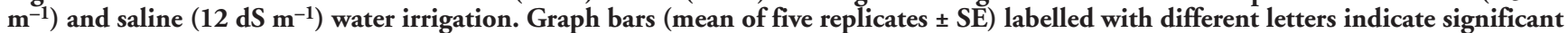
differences between genotypes within a growth stage for both salinity levels $(P \leq 0.05$, Tukey test). 
of salinity was more pronounced at flowering (Z65) and maturity (Z85) stages. The rhizosphere MBC and MBN contents for each growth stage were significantly different between durum wheat genotypes. The durum wheat landrace, 'Agili Glabre', and the improved variety, 'Maali', recorded the highest value of MBC and MBN.

Under the two distinct salinity irrigations $\left(0.3\right.$ and $\left.12 \mathrm{dS} \mathrm{m}^{-1}\right)$, 'Agili Glabre' and 'Maali' showed the highest MBC values at tillering (Z30) and flowering (Z65) growth stages (Figure 1). However, at $0.3 \mathrm{dS} \mathrm{m} \mathrm{m}^{-1}$, the highest $\mathrm{MBN}$ was observed for

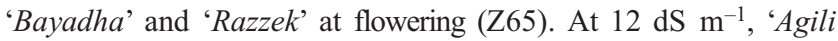
Glabre' and 'Maali' recorded the maximum MBN at tillering (Z30).

\section{Patterns of enzymatic activities}

In most cases, significant $(\mathrm{P} \leq 0.01)$ variations among the irrigation water salinity $(S)$, genotypes $(\mathrm{G})$, and their interaction $(\mathrm{S} \times \mathrm{G})$ for all tested enzymatic activities were obtained at each studied wheat growth stage (Table S2). Among the five sampling stages, the mean activity of D-ase was higher at the tillering (Z30), declined at the flowering (Z65), maintained the same activity at maturity (Z85), and dropped at harvest (Z92) (Table S2, Figure 2). For Alk-ase, the activity of this enzyme increased at the vegetative stage (Z30) and reached a maximum at flowering (Z65). The P-ase activity behaved differently compared to the other assessed enzymes. The highest amount of P-ase was observed at the first three growth stages (Z16, Z30, and Z65), then decreased at maturity
(Z85) to reach a minimum at harvest (Z92). Compared to the control $\left(0.3 \mathrm{dS} \mathrm{m}^{-1}\right)$, the mean enzymatic activities were severely reduced by salt stress. On average, P-ase (8-26\%) and Alk-ase (5$29 \%$ ) were less affected by salinity than D-ase (15-35\%). The three enzymes were altered differently throughout the growth cycle, e.g., the salt stress effect was more pronounced at maturity (Z85) and harvest (Z92) for D-ase, while tillering (Z30) and flowering (Z65) for Alk-ase. For each growth stage, genotypic variation was observed for enzyme activities. The maximum D-ase, Alk-ase, and P-ase activities occurred under the rhizosphere of 'Maali' and 'Agili Glabre'; however, 'Razzek' showed an important activity of P-ase compared to D-ase and Alk-ase.

In control $\left(0.3 \mathrm{dS} \mathrm{m}^{-1}\right)$, the best activities of the three enzymes were found for 'Maali', 'Razzek', and 'Agili Glabre' at the tillering (Z30) and flowering stages (Z65) (Figure 2). Using

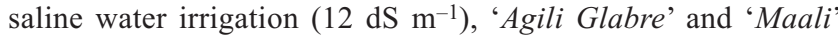
maintained considerable D-ase, Alk-ase, and P-ase activities with a peak at tillering (Z30) and flowering (Z65) stages. In contrast, 'Bayadha' showed reluctant activities during the whole crop growth.

\section{Variations of available phosphorus (available $P$ ) and nitrogen (available $\mathbf{N}$ ) in the soil}

The present investigation showed significant differences $(\mathrm{P} \leq 0.01)$ among genotypes $(\mathrm{G})$ and irrigation water salinity $(\mathrm{S})$ for almost all $\mathrm{P}$ and $\mathrm{N}$ contents (Table S3). Significant double interac-

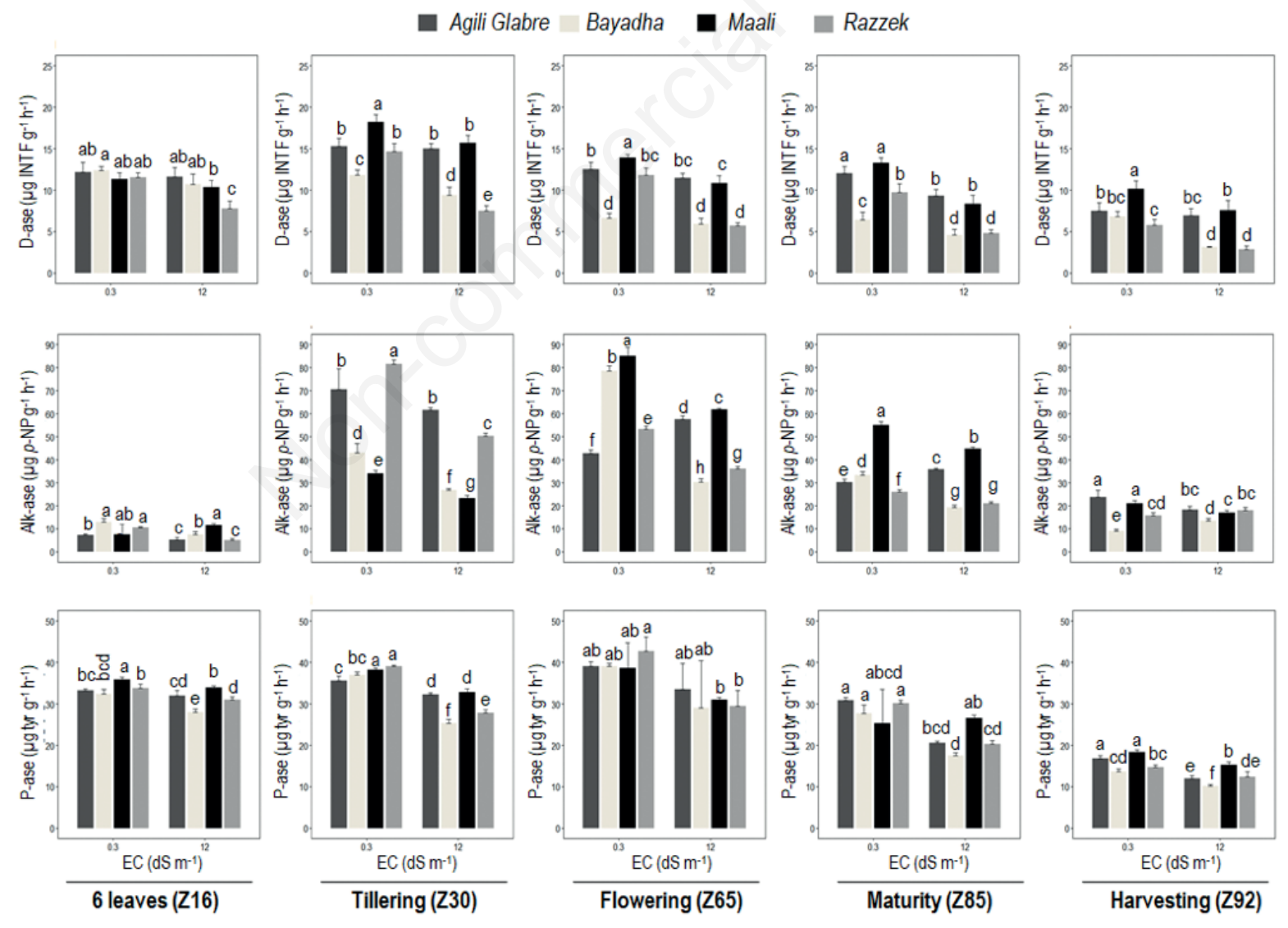

Figure 2. Variation of selected enzyme activities, dehydrogenase (D-ase), alkaline phosphatase (Alk-ase), and protease ( $P$-ase), at five growth stages of durum wheat crop under non-saline $\left(0.3 \mathrm{dS} \mathrm{m} \mathrm{m}^{-1}\right)$ and saline $\left(12 \mathrm{dS} \mathrm{m} \mathrm{m}^{-1}\right)$ water irrigation. Graph bars (mean of five replicates \pm SE) labelled with different letters indicate significant differences between genotypes within a growth stage for both salinity levels $(\mathbf{P} \leq \mathbf{0 . 0 5}$, Tukey test). 
tion $(\mathrm{S} \times \mathrm{G})$ was also observed $(\mathrm{P} \leq 0.05)$. The concentrations of available $\mathrm{P}$ and $\mathrm{N}$ increased with the crop stages up to the vegetative stage (Z30) and declined later at maturity (Z85) and harvest (Z92) (Table S3, Figure 3). The use of brackish water significantly decreased the mean of available $\mathrm{P}(16.46 \%)$ and $\mathrm{N}(27.35 \%)$. Available P was mostly affected at Z92 then Z85, respectively. However, the main reduction of available $\mathrm{N}$ was obtained at Z85 then Z65, respectively. Under these conditions, 'Maali' and 'Agili Glabre' showed the highest available $\mathrm{P}$ and $\mathrm{N}$ values, while 'Bayadha' exhibited the lowest values.

'Bayadha' was consistently the best performing genotype for available $P$ at the six leaves stage at both salinity levels $(0.3$ and 12 $\mathrm{dS} \mathrm{m}^{-1}$ ). After that, 'Maali', 'Agili Glabre', and 'Razzek' were the best genotypes, and their maxima were recorded at the tillering and flowering stages. Nonetheless, at the six leaves stage (Z16), the best available $\mathrm{N}$ contents were obtained in the rhizospheres of 'Maali' and 'Bayadha' under contrast salinity conditions. At tillering stage (Z30), 'Maali' followed by 'Agili Glabre' and 'Razzek' showed, however, the most significant available $\mathrm{N}$ values at $0.3 \mathrm{dS}$ $\mathrm{m}^{-1}$. Finally, at the high salinity level $\left(12 \mathrm{dS} \mathrm{m}^{-1}\right)$, 'Maali', and to another extent 'Agili Glabre', recorded the highest values of available $\mathrm{N}$ across the growth cycle, reaching a maximum at the flowering stage (Z65).

\section{Differences of durum wheat grain yield among treatments}

Significant variations $(\mathrm{P} \leq 0.001)$ among genotypes $(\mathrm{G})$ and level of salinity (S) were obtained for the number of grains per plant (NG) and the grain yield (GY) (Table S4). In addition, the S $\times \mathrm{G}$ interaction showed a significant $(\mathrm{P} \leq 0.001)$ effect on all tested yield parameters (i.e., NG, GY). Our results revealed that the use of brackish water negatively affected the yield parameters by
$6.42 \%$ and $26.30 \%$ for NG and GY, respectively (Table S4, Figure 4). Interestingly, the mean NG was higher for the improved commercial varieties, 'Maali' and 'Razzek', while the maximum GY values were obtained for the improved variety 'Maali' and the landrace 'Agili Glabre'.

Under control conditions $\left(0.3 \mathrm{dS} \mathrm{m} \mathrm{m}^{-1}\right)$, 'Maali' and 'Bayadha' recorded the highest NG (Figure 4). However, 'Maali' and 'Razzek' showed the maximum values at $12 \mathrm{dS} \mathrm{m}^{-1}$. Like $\mathrm{NG}$, the data showed a divergent genotype pattern for GY. At $0.3 \mathrm{dS} \mathrm{m}^{-1}$, the highest GY were registered for 'Maali' and 'Razzek'; while maximum GY were recorded at $12 \mathrm{dS} \mathrm{m}^{-1}$ for 'Maali' and Agili Glabre'.

\section{Correlation and stepwise analysis of investigated parameters}

Specific interactions between soil chemical and biological parameters were obtained according to salinity levels $(0.3$ and 12 $\mathrm{dS} \mathrm{m}^{-1}$ ) and physiological growth stages (Z16, Z30, Z65, Z85, and Z92) (Figure 5). Overall, positive correlations among MBCMBN, enzymatic activities (D-ase, Alk-ase, and P-ase), and available elements (available $\mathrm{P}$ and $\mathrm{N}$ ) were recorded. Those correlations were more marked at $12 \mathrm{dS} \mathrm{m}^{-1}$ than those at control conditions $\left(0.3 \mathrm{dS} \mathrm{m}^{-1}\right)$. The same trend was also observed between available elements (available $\mathrm{P}$ or $\mathrm{N}$ ) and biological parameters (MBC, MBN, D-ase, Alk-ase, and P-ase) and between microbial biomass and enzymatic activities. The maximum significant correlations $(\mathrm{P} \leq 0.01 ; \mathrm{P} \leq 0.001)$ were obtained at $12 \mathrm{dS} \mathrm{m}^{-1}$ water irrigation salinity and those at tillering (Z30), maturity (Z85), and harvest (Z92).

The relationship between durum wheat GY and the rhizosphere parameters is dependent on genotype and irrigation water salinity (Figure 6). Under both salinity levels, the most positive

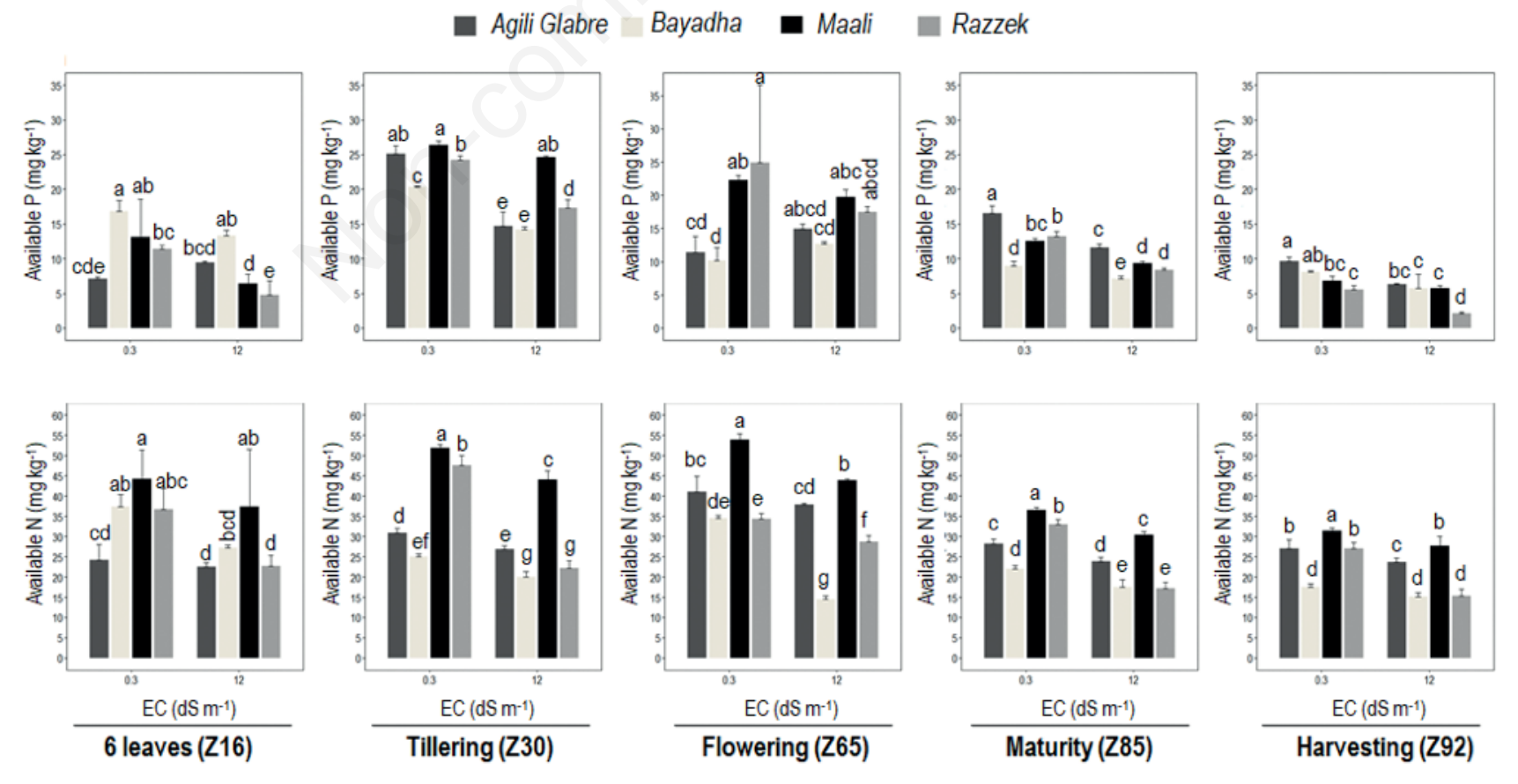

Figure 3. Available phosphorus (available $\mathrm{P}$ ) and nitrogen (available $\mathrm{N}$ ) at five growth stages of durum wheat crop under non-saline

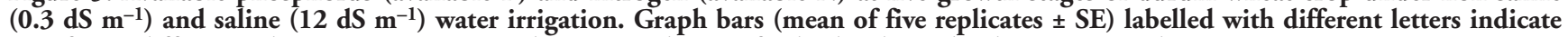
significant differences between genotypes within a growth stage for both salinity levels $(\mathrm{P} \leq 0.05$, Tukey test). 
significant correlations $(\mathrm{P} \leq 0.05)$ were obtained for 'Agili Glabre', 'Maali' followed by 'Bayadha'. At $12 \mathrm{dS} \mathrm{m}{ }^{-1}$, maximum significant correlations were found between GY of those genotypes and soil parameters. Notably, available N, P-ase, available P, Alk-ase, and D-ase were linked with GY under both control and saline conditions. The regressions were less marked for $\mathrm{MBC}, \mathrm{MBN}$, and the ratio $\mathrm{MBC} / \mathrm{MBN}$ at $12 \mathrm{dS} \mathrm{m}^{-1}$, while no significant correlation was obtained with $\mathrm{MBN}$ and $\mathrm{MBC} / \mathrm{MBN}$ at $0.3 \mathrm{dS} \mathrm{m}^{-1}$.

To assess the relative contribution of the biochemical proper- ties of soil in predicting the GY, we performed a multiple regression analysis according to a stepwise procedure. The GY was the dependent variable, while soil biochemical parameters (i.e., MBC, MBN, D-ase, Alk-ase, P-ase, and available P and N) were used as independent variables (predictors). The selected predictor variables depended on durum wheat growth stages and soil salinity levels, which makes it challenging to build a predictive model with all soil characteristics (Figure 7). Overall, at $12 \mathrm{dS} \mathrm{m}^{-1}, \mathrm{MBC}$, available $\mathrm{N}$, Alk-ase, and $\mathrm{P}$-ase seem to play a key role in predict-
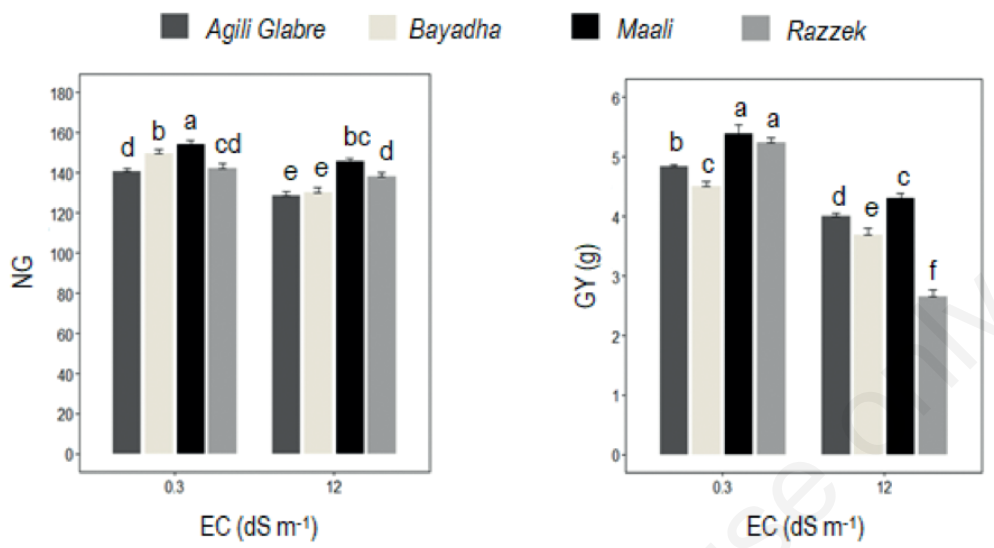

Figure 4. The grain number per plant (NG) and grain yield per plant (GY) of four durum wheat genotypes as affected by irrigation water salinity $\left(0.3\right.$ and $\left.12 \mathrm{dS} \mathrm{m}^{-1}\right)$. Graph bars (mean of five replicates \pm SE) labelled with different letters indicate significant differences between genotypes for both salinity levels $(P \leq 0.05$, Tukey test).

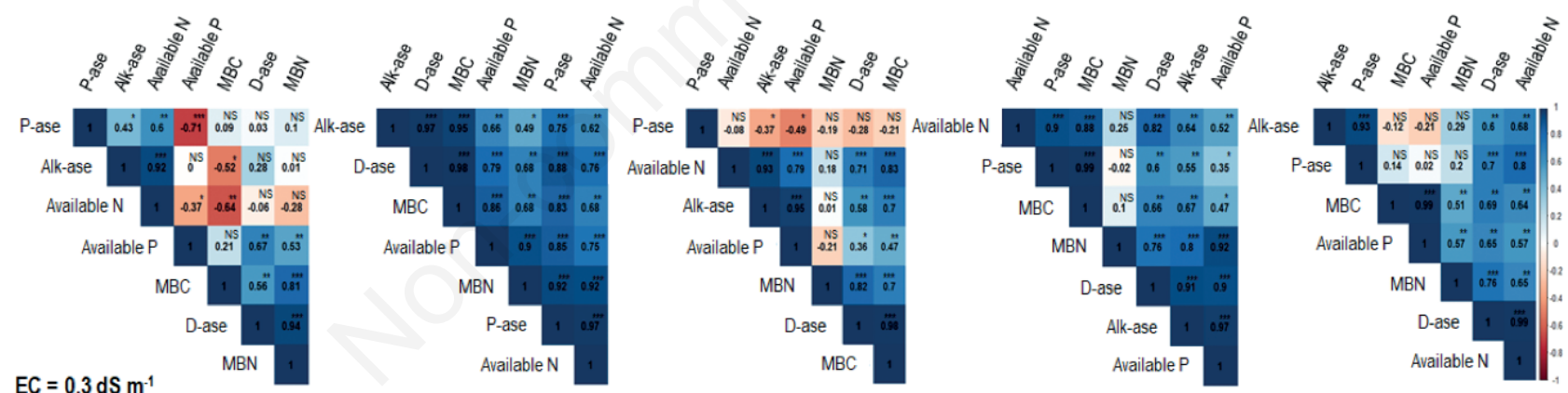

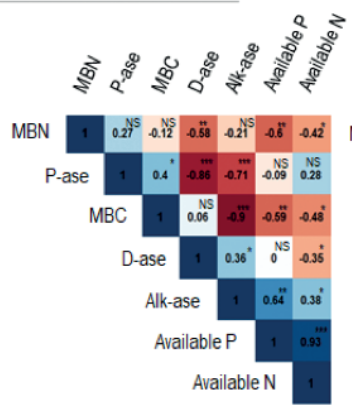

6 Leaves (Z16)

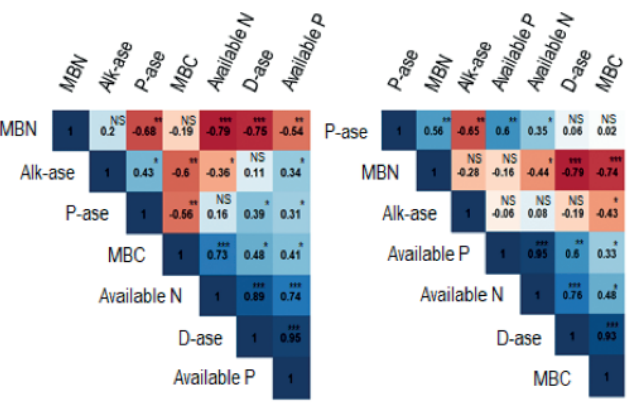

Tillering (Z30)

Flowering (Z65)

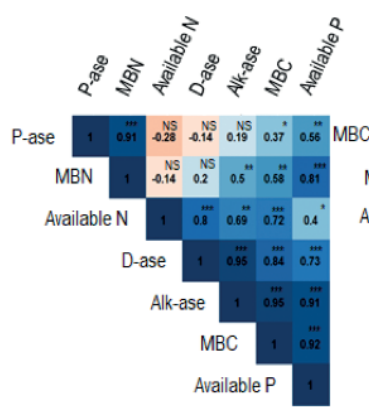

Maturity (Z85)

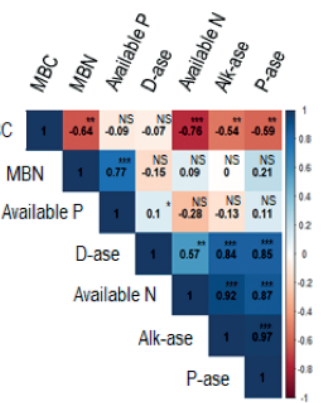

Harvesting (Z92)

Figure 5. Pearson correlation analysis between microbial biomass ( $\mathrm{MBC}$ and $\mathrm{MBN}$ ), enzyme activities (D-ase, Alk-ase, and $\mathrm{P}$-ase), and mineral nutrients (available $P$ and $N$ ) at a particular physiological stage under non-saline $\left(0.3 \mathrm{dS} \mathrm{m} \mathrm{m}^{-1}\right)$ and saline $\left(12 \mathrm{dS} \mathrm{m}^{-1}\right) \mathrm{water}^{-1}$ irrigation. Red and blue rectangles show negative and positive correlations, respectively. The $\mathbf{r}$ values were obtained from 20 observations (4 genotypes and 5 replicates). ${ }^{*}, * *,{ }^{* *}$ Significant at $P \leq 0.05, P \leq 0.01$, and $P \leq 0.001$, respectively. NS, not significant. See Figures 1,2 , and 3 for abbreviations. 

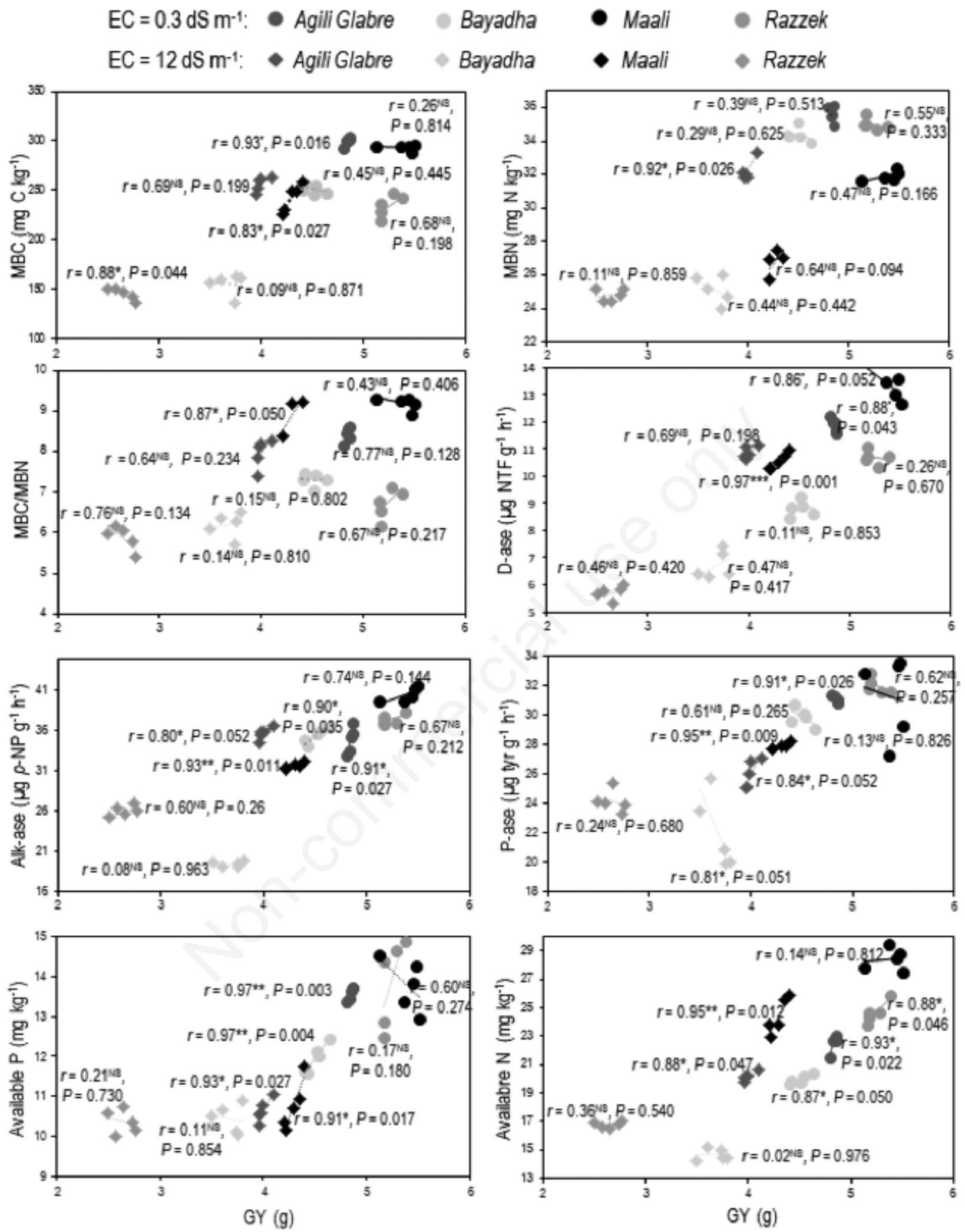

Figure 6. Relationship between grain yield (GY) and microbial biomass (MBC, MBN, and MBC/MBN ratio), enzyme activities (D-ase, Alk-ase, and $\mathrm{P}$-ase), and with mineral nutrients (available $\mathrm{P}$ and $\mathrm{N}$ ) of four durum wheat genotypes under non-saline $\left(0.3 \mathrm{dS} \mathrm{m}^{-1}\right)$ and saline $\left(12 \mathrm{dS} \mathrm{m}^{-1}\right)$ water irrigation. Each point is the average value of five replicates of each crop growth stage. ${ }^{*},{ }^{* *},{ }^{* * *}$ Significant at $P \leq 0.05, P \leq 0.01$, and $P \leq 0.001$, respectively. NS, not significant. Circles indicate different genotypes at $0.3 \mathrm{dS} \mathrm{m}^{-1} ; D^{2}$ iamonds indicate different genotypes at $12 \mathrm{dS} \mathbf{~ m}^{-1}$. Black color = 'Maali'; Very dark grey = 'Agili Glabre'; Dark grey = 'Razzek'; Light grey = 'Bayadha'. See Figures 1, 2, and 3 for abbreviations. 
ing GY, while, at $0.3 \mathrm{dS} \mathrm{m}^{-1}$, Alk-ase and available $\mathrm{P}$ have greatly influenced this aboveground trait.

\section{Discussion}

\section{Impact of irrigation water salinity on investigated parameters}

The irrigation with saline water $\left(12 \mathrm{dS} \mathrm{m}^{-1}\right)$ significantly altered the soil biological (i.e., MBC, MBN, D-ase, Alk-ase, and Pase), chemical (i.e., available $\mathrm{P}$ and $\mathrm{N}$ ), and durum wheat yield parameters (NG and GY).

The decline of MBC and MBN in salt-affected soil has already been observed by Elmajdoub and Marschner (2015) and Zhang et al. (2019). The first authors attributed this decline to a decrease of labile organic $\mathrm{C}$ fraction, including easily oxidizable organic $\mathrm{C}$, and/or increased soil osmotic pressure and ion accumulation in microbial cells. Thus, salinity could affect microorganisms by killing cells. Otherwise, the decrease of MBN might be due to the inhibited microbial $\mathrm{N}$ immobilisation under salt stress (Zhou et al., 2017). Conversely, the best-suited microorganisms to saline conditions may persist by accumulating osmolytes (Hagemann, 2011).

The present investigation revealed a negative effect of salinity on the microbial enzymatic activities of D-ase, Alk-ase, and P-ase. The decline of the enzymatic activities might be ascribed to the following explanations: i) microbial cells osmotic stress; ii) changes in specific ion toxicities that cause nutritional imbalances for microbial growth; and/or iii) microbial communities that devote less resource to the production and release of proteins into the medium. Facing low osmotic potentials, high salt concentrations denature proteins, reduce their solubility, and consequently, their activity (Frankenberger and Bingham, 1982). On the other hand, the saline soil $\left(12 \mathrm{dS} \mathrm{m}^{-1}\right)$ was characterised by an excessive $\mathrm{Na}^{+}$, which, in turn, has a deleterious effect on soil aggregate stability by increasing clay dispersion. Thus, the extracellular enzymes are less protected and become more susceptible to proteolysis. Our results showed that P-ase activity remained the least affected by salinity than D-ase and Alk-ase. This result might be partly explained by the chemical composition of the enzyme (Singh, 2016) and/or the formation of humus complexes that might protect some enzymes more than others (Guangming et al., 2017). Another possibility is that soil microbial species that produce protease are more resistant to salinity.

Our experiment showed that salinity disturbed the availability of the two nutrients (available P and N). This finding could be attributed to the fact that salinity negatively affects the two origins of available $\mathrm{P}$ in the rhizosphere, microorganisms, and root secretions. In addition, salinity might have indirectly decreased the amount of available N. Salt stress seems to alter microbial growth and activity, thereby reducing the organic matter decomposition responsible for forming the mineral parts of nutrients. Otherwise, under osmotic stress, microorganisms try to ensure their survival by increasing $\mathrm{C}$ and $\mathrm{N}$, which leads to a change in $\mathrm{C} / \mathrm{N}$ ratio, and thus a decline in soil $\mathrm{C}$ and $\mathrm{N}$ mineralisation rates (Chen et al., 2013).

\section{Interaction between durum wheat genotypes and their rhizosphere biochemistry according to growth stages}

The fluctuation in microbial biomass- $\mathrm{C}$ and $-\mathrm{N}$, and soil enzymatic activities (D-ase, Alk-ase, and $\mathrm{P}$-ase) responds to interactions between the tested durum wheat genotypes and the rhizo-

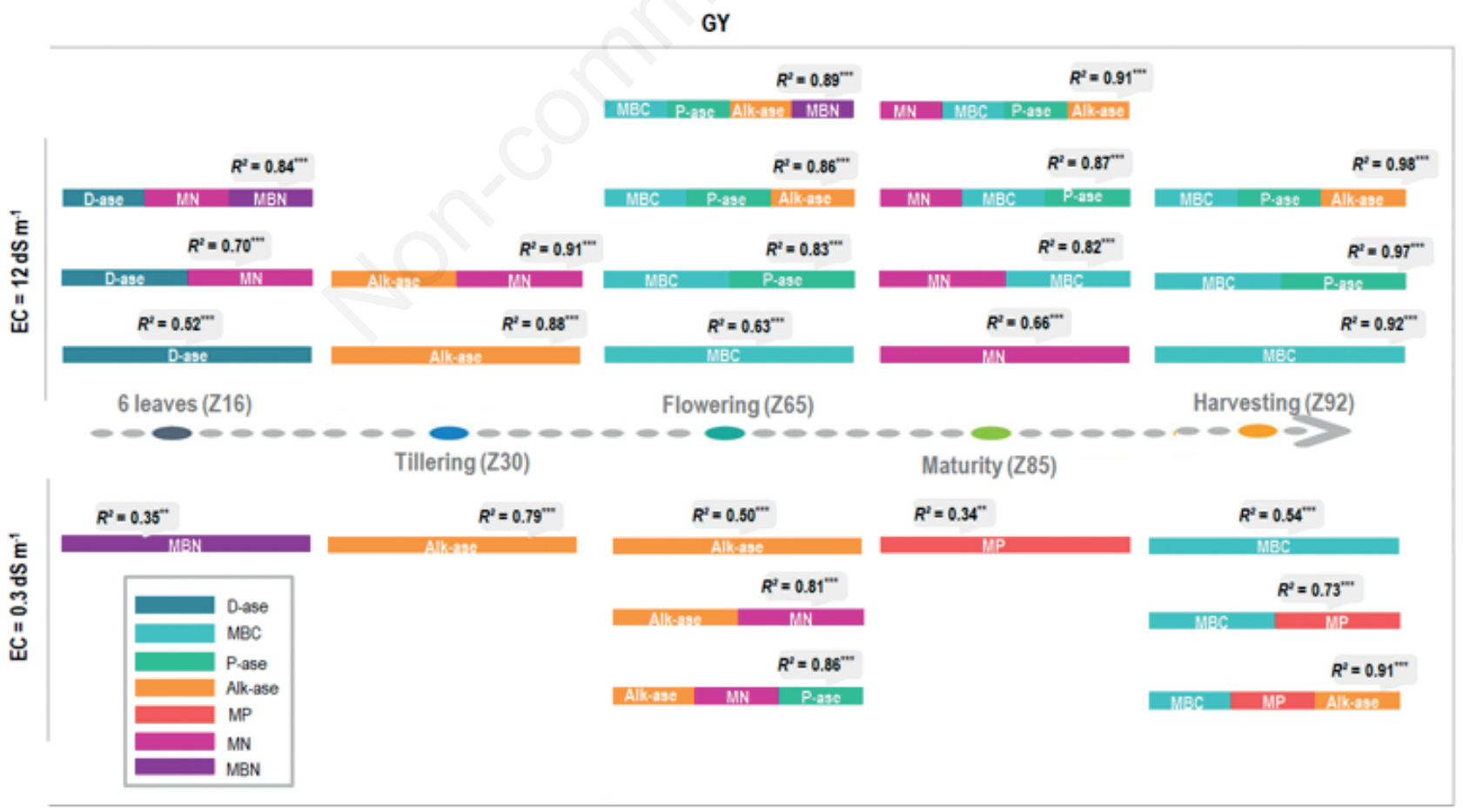

Figure 7. Stepwise analysis explaining grain yield (GY) variation at a particular physiological stage in each environment $(0.3$ and $12 \mathrm{dS}$ $\mathrm{m}^{-1}$ ), as a dependent variable, with $\mathrm{MBC}$, MBN, D-ase, Alk-ase, $\mathrm{P}$-ase, available $\mathrm{P}$, and available $\mathrm{N}$ as independent variables. $* *, * * *$ Significant at $\mathbf{P} \leq \mathbf{0 . 0 1}$ and $\mathrm{P} \leq 0.001$, respectively. See Figures $\mathbf{1}, 2$, and 3 for abbreviations. 
sphere-associated microorganisms during the growth cycle. In most cases, these activities were more notable at tillering (Z30), and flowering (Z65), and they relapsed at maturity (Z85) and after harvest (Z92). The maximum enzymatic activities at the vegetative growth stage could be due to genotypes vigorous growth rate, including root development (Jin et al., 2009), while the decrease in these activities at the end of the cycle might be explained by low root exudation, change of root exudates composition, including amino acids that control the synthesis of enzymes as P-ase (Jezierska-Tys et al., 2012), and/or disrepair of the exuded molecules affecting microbial activity (Gransee and Wittenmayer, 2000). The observed trend differed from that found by Jat et al. (2020), who obtained the lowest MBC and MBN at the wheat tillering stage and the highest levels near harvest. Our results are consistent with previous findings showing a significant seasonal effect on Alk-ase wheat rhizosphere (Mandal et al., 2007) as well as D-ase maize rhizosphere (Tamilselvi et al., 2015). In particular, at tillering, 'Agili Glabre' (landrace) showed the highest MBC, MBN, and Alk-ase. However, at flowering, 'Maali' (improved variety) exhibited the highest activity of $\mathrm{MBC}$, D-ase, and Alk-ase followed by 'Agili Glabre'. In response to variation in root morphology and biomass and root exudation in terms of quantity and quality (İnceoğlu et al., 2010; Corneo et al., 2016; Iannucci et al., 2021), the microorganisms originally present in the rhizosphere interact with genotypes and growth stages. According to genotypes, the exuded molecules form rhizodeposits that interact with soil microorganisms, thereby affecting the enzymatic activity differently (Zuo et al., 2014). This finding agrees with other studies showing a significant effect of wheat genotypes on soil parameters (e.g., MBC and MBN), particularly those characterised by specific root lengths and the proportion of coarse roots (Corneo et al., 2016; Junaidi et al., 2018).

Like biological parameters, available $\mathrm{P}$ and $\mathrm{N}$ concentrations were higher at tillering (Z30) and flowering (Z65) stages and then gradually declined. We hypothesised that Ca uptake was important at these stages, which significantly increased rhizosphere $\mathrm{P}$ availability (Devau et al., 2010). Interestingly, the content of available $\mathrm{P}$ was much higher under the rhizosphere of 'Maali' and 'Agili Glabre' at tillering and flowering. This fact suggests that organic ligand exuded by roots of those genotypes, which interacted with rhizosphere microorganisms, might increase via ligand exchange, promoting $\mathrm{P}$ desorption at these stages. In addition, Harmsen (2007) mentioned that each genotype develops a bio-influenced zone where the $\mathrm{P}$ availability is significantly influenced. Our previous investigation showed a variable accumulation level of $\mathrm{P}$ in leaves according to genotypes and growth stages (Boudabbous et al., 2019) that might be attributed to a differential absorption ability and, thus, causes the variability of soil P.

The variability of available $\mathrm{N}$ during crop life cycle might originate from: i) differential absorption by genotypes (Barraclough et al., 2014); ii) root development that makes N more available (Liu et al., 2018); and/or iii) an increase of organic acid exudations at active stages (e.g., flowering stage) (Canarini et al., 2019). Both genotypes, 'Maali' and 'Agili Glabre', might accumulate more microorganisms near their roots, thus having beneficial effects on plants, including mycorrhizal fungi and $\mathrm{N}$ fixers (Bever, 2015), increasing $\mathrm{N}$ mineralisation at tillering and flowering. Besides, soil available $\mathrm{N}$ dynamic depends on genotype uptake aptitude (Junaidi et al., 2018). Plants compete with nitrifying microorganisms with a rapid uptake, dense root systems, or regulation of oxygen availability (Glaser et al., 2010). According to genotypes, the distinct response of available $\mathrm{N}$ could be attributed to a differential exudation by roots and/or hydrolysis of organic matter via microbial enzymes.

Genotypes differed considerably regarding NG and GY. GY difference between genotypes was mainly attributed to NG that should be associated with a reduction in floret viability for sensitive genotypes (Francois et al., 1994). More importantly, 'Maali' and 'Agili Glabre' showed the highest NG and GY under saline conditions, which might indicate positive feedback between the roots of these two genotypes and salt-tolerant microorganisms.

It is worth noting that the difference between genotypes could be accentuated according to the soil biota-genotype interactions that seem to modulate their below beneficially - and aboveground properties (e.g., available $\mathrm{P}$ and $\mathrm{N}$, and GY) in response to the salinity. Considering the durum wheat genotypes, 'Maali' and 'Agili Glabre' were the least affected by salinity, as reflected by microbial indicators and nutrient availability. Finally, we can suggest that tillering and flowering could be key steps in overcoming the salinity effects of genotypes.

\section{Correlation between chemical and biological soil parameters and their relationship with grain yield}

To fully understand the role of soil properties under the rhizosphere of plant genotype on GY, we will need to encompass both chemical and biological interactions. Using saline water irrigation (12 $\mathrm{dS} \mathrm{m}^{-1}$ ), important positive and significant interactions between chemical (available $\mathrm{P}$ and $\mathrm{N}$ ) and biological parameters (MBC, MBN, D-ase, Alk-ase, and P-ase) were obtained. Our result suggests a greater rhizospheric microorganism's investment at severe stress conditions to mitigate the deleterious salt effects. For both salinity conditions, specific interactions were observed according to the physiological growth stages. A significant relationship between chemical and biological traits was found, in particular, at the tillering and maturity stages in salt-affected soil. Overall, at $12 \mathrm{dS} \mathrm{m}^{-1}, \mathrm{MBC}$ and $\mathrm{MBN}$ were significantly positively linked with the three enzyme activities (D-ase, Alk-ase, and Pase). In our case, the MBC and MBN showed a stronger relationship with D-ase than Alk-ase and P-ase.

Mineral nutrition deficiency or efficiency (e.g., available $\mathrm{P}$ and N) depends on rhizosphere microorganisms' competition with the plant roots (Jingguo and Bakken, 1997). In the current study, we observed a significant interaction between biological parameters ( $\mathrm{MBC}$ and $\mathrm{MBN}$ ) and available elements (available $\mathrm{P}$ or N), more pronounced at saline conditions. On the other hand, available $\mathrm{P}$ and $\mathrm{N}$ were correlated positively with the microbial enzyme activities (D-ase, Alk-ase, and P-ase) at both salinity levels. It is well known that rhizosphere availability of $\mathrm{P}$ was stimulated by the exudation and $\mathrm{P}$ hydrolysing enzymes activities (Maseko and Dakora, 2013). On the opposite hand, Allison et al. (2007) reported a negative relationship between $\mathrm{P}$ and Alk-ase, and Bowles et al. (2014) observed no significant correlation under wheat-maize rotation. Mineralisation and immobilisation of organic $\mathrm{N}$ are also mediated by several enzymatic processes, including protease derived from microorganisms. In our study, the significant positive correlation between available $\mathrm{N}$ and $\mathrm{P}$-ase activity indicates positive feedback between durum wheat genotypes and microorganisms that produce $\mathrm{P}$-ase to make $\mathrm{N}$ available to the plant. This correlation might also be attributed to increased $\mathrm{N}$ demand to build up microbial biomass stimulated by durum wheat root exudates (Wang and Tang, 2018). This result was further confirmed by significant correlations between MBC and available $\mathrm{N}$ and MBC and P-ase. D-ase activity was the most correlated with available $\mathrm{P}$ and $\mathrm{N}$ for both salinity levels when comparing the three enzymes.

In practice, the crop yield is the result of all soil physical, chemical, and biological interactions (Diallo-Diagne et al., 2016). To the best of our knowledge, this is the first report aimed to highlight the critical biochemical factors which are significantly associated with the GY of four durum wheat genotypes under non-saline and saline conditions. 
The results showed that the relationship between GY and soil parameters was complex and depended on the genotype's rhizosphere and water salinity levels $\left(0.3\right.$ and $\left.12 \mathrm{dS} \mathrm{m}^{-1}\right)$. For both salinity levels, the GY of the two genotypes, 'Agili Glabre' and 'Maali', followed by 'Bayadha' was exceptionally correlated with their belowground traits.

Our data revealed a clear positive association between available N, P-ase, available P, Alk-ase, D-ase, and GY of those genotypes at low and high salinity levels. Therefore, it was thought that changes in soil enzyme activities might be a possible mechanism to explain yield fluctuation during soil organic transition (Karasawa et al., 2015). Furthermore, we expected that genotypes with more significant belowground inputs would exhibit greater biological mineralisation and thus plant nutrient uptake.

Otherwise, $\mathrm{MBC}, \mathrm{MBN}$, and the $\mathrm{MBC} / \mathrm{MBN}$ ratio were weakly correlated with GY at saline conditions. Invariable of salt stress, those observations were already noticed by Mikanová et al. (2012), who did not find under field conditions any relationship between wheat GY and MBC. However, Silva et al. (2010) reported that higher MBC and MBN were associated with higher GY.

The correlations found here for biochemical parameters were slightly greater in saline conditions than those of non-saline conditions, emphasising that this behaviour could be due to: i) enhanced microbial activity and biomass following a greater exudation of $\mathrm{C}$ by roots of tolerant genotypes (e.g., 'Maali' and 'Agili Glabre'); ii) the activation of the relative microbial encoding gene promoted by durum wheat rhizosphere; and/or iii) the activation of salt-adapted microorganisms following the increase of soil salinity.

The predictive relationships (stepwise analysis) support the effect of soil properties on durum wheat yield. Intriguingly, the predictors depended on crop physiological growth stages and salinity levels. This is undoubtedly due to the complexity of plant response interacting with the external environment. Overall, $\mathrm{MBC}$, available N, Alk-ase, and P-ase were the determinant components of GY variability under saline conditions.

\section{Conclusions}

The present study highlights the involvement of microorganisms in moderating the adverse effects of salinity on durum wheat productivity. In fact, the rhizosphere genotypes of 'Maali' and 'Agili Glabre' as reflected by microbial biomass, enzymatic activity, and nutrient availability, lead to salt stress mitigation. This is the first report aiming to explore the link between soil biochemical factors and GY under contrast salinity conditions. The findings support the beneficial interaction between roots and soil biota. The positive relationship between biological (MBC, MBN, D-ase, Alkase, and $\mathrm{P}$-ase) and chemical (available $\mathrm{P}$ and $\mathrm{N}$ ) parameters indicates the involvement of the microbial process in maintaining soil fertility. Besides, tillering and flowering could be considered as key stages to assess durum wheat salinity tolerance. Notably, available N, P-ase, P, Alk-ase, and D-ase might be useful criteria for quantifying the yield of salt-tolerant genotypes (i.e., 'Maali' and 'Agili Glabre'). However, the stepwise analysis revealed that $\mathrm{MBC}$, available N, Alk-ase, and P-ase were the determinant components of GY variability under salinity. The effect of salinity on rhizospheric parameters and wheat GY appeared to be complex, and it should be investigated by identifying all microorganisms within a genotype's rhizosphere.

\section{References}

AFNOR, 1995. Quality control of soil analyzes. Methods of official analyzes-Tome 1 (in French). AFNOR-DGCCRF, Association Française de Normalisation, Paris, France.

Allison VJ, Condron LM, Peltzer DA, Richardson SJ, Turner BL, 2007. Changes in enzyme activities and soil microbial community composition along carbon and nutrient gradients at the Franz Josef chronosequence, New Zealand. Soil Biol. Biochem. 39:1770-81.

Barraclough PB, Lopez-Bellido R, Hawkesford MJ, 2014. Genotypic variation in the uptake, partitioning and remobilisation of nitrogen during grain-filling in wheat. Field Crop Res. 156:242-8.

Bera T, Sharma S, Thind HS, Singh Y, Sidhu HS, Jat ML, 2018. Changes in soil biochemical indicators at different wheat growth stages under conservation-based sustainable intensification of rice-wheat system. J. Integr. Agric. 17:1871-80.

Bever JD, 2015. Preferential allocation, physio $\square$ evolutionary feedbacks, and the stability and environmental patterns of mutualism between plants and their root symbionts. New Phytol. 205:1503-14.

Biro Turk K, Aljughaiman AS, 2020. Land use/land cover assessment as related to soil and irrigation water salinity over an oasis in arid environment. Open Geosci. 12:220-31.

Boudabbous Kh, Bouhaouel I, Karmous C, Benaissa N, Trifa Y, Sahli A, Slim Amara H, 2019. The variation of phosphorous content, grain yield, and rhizosphere microbial biomass among durum wheat cultivars under salinity stress. Arch. Agron. Soil Sci. 66:1721-34.

Boudabbous Kh, Ben Aissa N, Trifa Y, Sahli A, Slim Amara H, 2016. Soil microorganisms alleviates the negative effect of salinity on morphophysiological characteristics during growth stages of durum wheat genotypes. JNS 28:1622-30.

Bowles TM, Acosta-Martínez V, Calderón F, Jackson LE, 2014. Soil enzyme activities, microbial communities, and carbon and nitrogen availability in organic agroecosystems across an intensively-managed agricultural landscape. Soil Biol. Biochem. 68:252-62.

Boyrahmadi M, Raiesi F, 2018. Plant roots and species moderate the salinity effect on microbial respiration, biomass, and enzyme activities in a sandy clay soil. Biol. Fert. Soils 54:50921.

Brookes PC, Landman A, Pruden G, Jenkinson DS, 1985. Chloroform fumigation and the release of soil nitrogen: a rapid direct extraction method to measure microbial biomass nitrogen in soil. Soil Biol. Biochem. 7:837-42.

Canarini A, Kaiser C, Merchant A, Richter A, Wanek W, 2019. Root exudation of primary metabolites: mechanisms and their roles in plant responses to environmental stimuli. Front. Plant Sci. 10:157.

Chaabane R, Bchini H, Ouji H, Ben Salah H, Khamassi K, Khoufi S, Babay E, Ben Naceur M, 2011. Behaviour of Tunisian durum wheat (Triticum turgidum L.) varieties under saline stress. Pak. J. Nutr. 6:539-42.

Chen YX, Li HH, Zhou T, Chen XP, Huang W, Liu J, Zhang CC, $\mathrm{Xu} \mathrm{KW,} \mathrm{2013.} \mathrm{Effects} \mathrm{of} \mathrm{phosphorus} \mathrm{fertilization} \mathrm{on} \mathrm{leaf} \mathrm{area}$ index, biomass accumulation and allocation, and phosphorus use efficiency of intercropped maize. J. Appl. Ecol. 24:2799806.

Corneo PE, Suenaga H, Kertesz MA, Dijkstra FA, 2016. Effect of twenty four wheat genotypes on soil biochemical and microbial properties. Plant Soil 404:141-55.

Devau N, Le Cadre E, Hinsinger P, Gérard F, 2010. A mechanistic 
model for understanding root-induced chemical changes controlling phosphorus availability. Ann. Bot. 105:1183-97.

Diallo-Diagne NH, Assigbetse K, Sall S, Masse D, Bonzi M, Ndoye I, Chotte JL, 2016. Response of soil microbial properties to long-term application of organic and inorganic amendments in a tropical soil (Saria, Burkina Faso). OJSS 6:21-33.

Elmajdoub B, Marschner P, 2015. Responses of soil microbial activity and biomass to salinity after repeated additions of plant residues. Pedosphere 25:177-85.

Fageria NK, Gheyi HR, Moreira A, 2011. Nutrient bioavailability in salt affected soils. J. Plant Nutr. 34:945-62.

Francois LE, Grieve CM, Maas EV, Lesch SM, 1994. Time of salt stress affects growth and yield components of irrigated wheat. Agron. J. 86:100-7.

Frankenberger WT, Bingham FT, 1982. Influence of salinity on soil enzyme activities. Soil Sci. Soc. Am. J. 46:1173-7.

Frija I, Frija A, Chebil A, Cheikh M'Hamed H, Speelman S, Makhlouf M, 2014. Marginal water productivity of irrigated durum wheat in semi-arid Tunisia. J. Agr. Sci. 6:84-95.

Glaser K, Hackl E, Inselsbacher E, Strauss J, Wanek W, Zechmeister-Boltenstern S, Sessitsch A, 2010. Dynamics of ammonia-oxidizing communities in barley-planted bulk soil and rhizosphere following nitrate and ammonium fertilizer amendment. FEMS Microbiol. Ecol. 74:575-91.

Gransee A, Wittenmayer L, 2000. Qualitative and quantitative analysis of water-soluble root exudates in relation to plant species and development. J. Plant Nutr. Soil Sci. 163:381-5.

Guangming L, Xuechen Z, Xiuping W, Hongbo S, Jingsong Y, Xiangping W, 2017. Soil enzymes as indicators of saline soil fertility under various soil amendments. Agric. Ecosyst. Environ. 237:274-9.

Hagemann M, 2011. Molecular biology of cyanobacterial salt acclimation. FEMS Microbiol. Rev. 35:87-123.

Harmsen J, 2007. Measuring bioavailability: from a scientific approach to standard methods. J. Environ. Qual. 36:1420-8.

Iannucci A, Canfora N, Nigro F, De Vita P, Beleggia R, 2021. Relationships between root morphology, root exudate compounds and rhizosphere microbial community in durum wheat. Appl. Soil Ecol. 158:103781.

İnceoğlu O, Salles JF, van Overbeek L, van Elsas JD, 2010. Effects of plant genotype and growth stage on the betaproteobacterial communities associated with different potato cultivars in two fields. Appl. Environ. Microbiol. 76:3675-84.

Jat HS, Choudharya M, Datta A, Yadav AK, Meena MD, Devi R, Gathala MK, Jat ML, McDonaldd A, Sharma PC, 2020. Temporal changes in soil microbial properties and nutrient dynamics under climate smart agriculture practices. Soil Till. Res. 199:104595.

Jezierska-Tys S, Rachoń L, Rutkowska A, Szumiło G. 2012. Effect of new lines of winter wheat on microbiological activity in Luvisol. Int. Agrophys. 26:33-8.

Jin K, Sleutel S, Buchan D, De Neve S, Cai DX, Gabriels D, Jin JY, 2009. Changes of soil enzyme activities under different tillage practices in the Chinese Loess Plateau. Soil Till. Res. 104:115-20.

Jingguo W, Bakken LR, 1997. Competition for nitrogen during mineralization of plant residues in soil: microbial response to $\mathrm{C}$ and N availability. Soil Biol. Biochem. 29:163-70.

Junaidi J, Kallenbach CM, Byrne PF, Fonte SJ, 2018. Root traits and root biomass allocation impact how wheat genotypes respond to organic amendments and earthworms. PLoS One 7:e0200646.

Karasawa T, Takebe M, Sato F, Komada M, Nagaoka K, Takenaka M, Urashima Y, Nishimura S, Takahashi S, Kato N, 2015. Trends of lettuce and carrot yields and soil enzyme activities during transition from conventional to organic farming in an Andosol. Soil Sci. Plant Nutr. 61:295-311.

Kumar S, Chaudhuri S, Maiti SK, 2013. Soil dehydrogenase activity in natural and mine soil - A review. Mid. E. J. Sci. Res. 13:898-906

Ladd JN, Butler JHA, 1972. Short-term assays of soil proteolytic enzyme activities using proteins and dipeptide derivatives as substrates. Soil Biol. Biochem. 4:19-30.

Liu W, Wang J, Wang C, Ma G, Wei Q, Lu H, Xie Y, Ma D, Kang $\mathrm{G}, 2018$. Root growth, water and nitrogen use efficiencies in winter wheat under different irrigation and nitrogen regimes in north China plain. Front. Plant Sci. 9:1798.

Lu H, Lashari MS, Liu X, Ji H, Li L, Zheng J, Kibue GW, Joseph $\mathrm{S}$, Pan G, 2015. Changes in soil microbial community structure and enzyme activity with amendment of biochar-manure compost and pyroligneous solution in a saline soil from Central China. Eur. J. Soil Biol. 70:67-76.

Mandal A, Patra AK, Singh D, Swarup A, Masto RE, 2007. Effect of long-term application of manure and fertilizer on biological and biochemical activities in soil during crop development stages. Bioresour. Technol. 98:3585-92.

Maseko ST, Dakora FD, 2013. Rhizosphere acid and alkaline phosphatase activity as a marker of $\mathrm{Pb}$ nutrition in nodulated Cyclopia and Aspalathus species in the Cape fynbos of South Africa. S. Afr. J. Bot. 89:289-95.

Mikanová O, Šimon T, Javůrek M, Vach M, 2012. Relationships between winter wheat yields and soil carbon under various tillage systems. Plant Soil. Environ. 58:540-4.

Munns R, James RA, Läuchli A, 2006. Approaches to increasing the salt tolerance of wheat and other cereals. J. Exp. Bot. 57:1025-43.

Olsen SR, Cole CV, Watanabe FS, Dean LA, 1954. Estimation of available phosphorus in soils by extraction with sodium bicarbonate. Circular 939. U.S. Dept of Agriculture, Washington, DC, USA.

Petard J, 1993. Soil analysis methods-Tome I (in French). IRD. ORSTOM, Nouméa, France.

Rassaa N, Bnejdi F, Chalh A, El Gazzah M, 2012. The validity of using juvenile stages for evaluation of salt stress tolerance of Triticum durum genotypes. Afr. J. Biotechnol. 9:2178-2189.

Sayar R, Bchini H, Mosbahi M, Ezzine M, 2010. Effects of salt and drought stresses on germination, emergence and seedling growth of durum wheat (Triticum durum Desf.). J. Agric. Res. 5:2008-16.

Shahbaz M, Ashraf M, 2013. Improving salinity tolerance in cereals. Crit. Rev. Plant Sci. 32:237-49.

Silva AP, Babujia LC, Franchini JC, Souza RA, Hungria M, 2010. Microbial biomass under various soil- and crop-management systems in short- and long-term experiments in Brazil. Field Crop Res. 119:20-26.

Singh K, 2016. Microbial and enzyme activities of saline and sodic soils. Land Degrad. Dev. 27:706-18.

Slim A, Piarulli L, Kourda HC, Rouaissi M, Robbana C, Chaabane R, Pignone D, Montemurro C, Mangini G, 2019. Genetic structure analysis of a collection of Tunisian durum wheat germoplasm. Int. J. Mol. Sci. 20:3362.

Tabatabai MA, Bremner JM, 1969. Use of p-nitrophenol phosphate for the assay of soil phosphatase activity. Soil Biol. Biochem. 1:301-7.

Tamilselvi SM, Chinnadurai C, Ilamurugu K, Arulmozhiselvan K, Balachandar D, 2015. Effect of long-term nutrient managements on biological and biochemical properties of semi-arid tropical Alfisol during maize crop development stages. Ecol. Indic. 48:76-87.

USDA, 2013. Soil classification: A comprehensives system (pre- 
pared by) soil survey staff. Government Printing Office, Washington, USA.

Vance ED, Brookes PC, Jenkinson DS, 1987. An extraction method for measuring soil microbial biomass C. Soil Biol. Biochem. 19:703-7.

Walkley A, Black IA, 1934. An examination of Degtjareff method for determining soil organic matter and a proposed modification of the chromic acid titration method. Soil Sci. 37:29-38.

Wang X, Tang C, 2018. The role of rhizosphere $\mathrm{pH}$ in regulating the rhizosphere priming effect and implications for the availability of soil-derived nitrogen to plants. Ann. Bot. 121:14351.

Waring SA, Bremner JM, 1964. Ammonium production in soil under waterlogged conditions as an index of nitrogen availability. Nature 201:951-2.

Wei T, Simko V, Levy M, Xie Y, Jin Y, Zemla J, 2017. Package 'corrplot'. Statistician 56:316-24.

Wickham H, 2009. ggplot2: Elegant graphics for data analysis.
Springer Science + Business, Media LLC, Berlin, Germany.

Zadoks JC, Chang TT, Konzak CF, 1974. A decimal code for the growth stages of cereals. Weed Res. 14:415-21.

Zhang WW, Wang C, Xue R, Wang LJ, 2019. Effects of salinity on the soil microbial community and soil fertility. J. Integr. Agric. 18:1360-8.

Zhou M, Butterbach-Bahl K, Vereecken H, Brüggemann N, 2017. A meta-analysis of soil salinization effects on nitrogen pools, cycles and fluxes in coastal ecosystems. Glob. Chang. Biol. 23:1338-52.

Zhu S, Huang X, Ho S-H, Wang L, Yang J, 2017. Effect of plant species compositions on performance of lab-scale constructed wetland through investigating photosynthesis and microbial communities. Bioresour. Technol. 229:196-203.

Zuo S, Li X, Ma Y, Yang S, 2014. Soil microbes are linked to the allelopathic potential of different wheat genotypes. Plant Soil 378:49-58. 